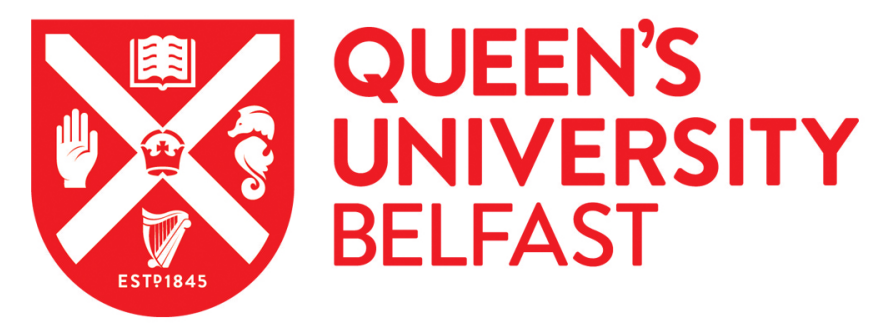

\title{
Dealing with the Legacy of Ethnic Conflict: Confronting 'Othering' through Transformative Adult Education-A Northern Ireland Case Study
}

McManus, C. (2017). Dealing with the Legacy of Ethnic Conflict: Confronting 'Othering' through Transformative Adult Education-A Northern Ireland Case Study. Ethnopolitics, 16(4), 411-429.

https://doi.org/10.1080/17449057.2016.1190142

Published in:

Ethnopolitics

Document Version:

Peer reviewed version

Queen's University Belfast - Research Portal:

Link to publication record in Queen's University Belfast Research Portal

Publisher rights

(C) 2016 The Editor of Ethnopolitics

This is an Accepted Manuscript of an article published by Taylor \& Francis in Ethnopolitics on 14th June 2016, available online:

http://www.tandfonline.com/10.1080/17449057.2016.1190142.

\section{General rights}

Copyright for the publications made accessible via the Queen's University Belfast Research Portal is retained by the author(s) and / or other copyright owners and it is a condition of accessing these publications that users recognise and abide by the legal requirements associated with these rights.

Take down policy

The Research Portal is Queen's institutional repository that provides access to Queen's research output. Every effort has been made to ensure that content in the Research Portal does not infringe any person's rights, or applicable UK laws. If you discover content in the

Research Portal that you believe breaches copyright or violates any law, please contact openaccess@qub.ac.uk. 
Dealing with the legacy of ethnic conflict: Confronting 'Othering' through transformative adult education - a Northern Ireland Case Study.

Dr Cathal McManus, Queen's University Belfast

\section{Queen's University Belfast}

School of Education

20 College Green,

Belfast, BT7 1LN

Tel: +44 (0)2890975914

Email: c.p.mcmanus@qub.ac.uk 


\title{
Dealing with the legacy of ethnic conflict: Confronting 'Othering' through transformative adult education - a Northern Ireland Case Study.
}

\begin{abstract}
Despite its peace process, Northern Ireland remains a deeply divided society. The legacy of a thirty year conflict has ensured the state continues to be prone to outbreaks of violence over contentious issues such as Orange Order parading and the flying of national flags.

This paper argues that in order to address this legacy there is a need to confront the Othering processes that have helped to generate and sustain division. It will argue that programmes of adult education can play an important role in helping the conflicting groups to reimagine their 'exclusive' notions of the nation to one capable of incorporating the 'other'.
\end{abstract}

\section{Key Words}

Othering; Conflict transformation; Adult education; Northern Ireland; Critical Consciousness theory 


\section{Introduction}

The Agreement, reached by political representatives from across the broad unionist and nationalist divide in 1998, represented a hugely significant moment in the history of Northern Ireland, bringing to an end, as it did, almost thirty years of military conflict (Bew, 2009). This conflict, which developed in the late 1960s, claimed the lives of over 3,500 people and injured thousands more (McKittrick, et al., 2004), and is seen to have its roots in a historic divide between those who support a continued political link with Britain (unionists) and those that support some form of unity with the Republic of Ireland (nationalists) (Jackson, 2004). ${ }^{1}$

Despite the undoubted success story that lies behind the development of the peace process, Northern Ireland remains a deeply divided society (Nolan, 2014). The legacy of the conflict, particularly the great sectarian divide that it helped to reinforce, has ensured that the state continues to be prone to outbreaks of violence over contentious issues such as Orange Order parading and the flying of national flags on civic buildings (Nolan, 2014; Nolan, et al., 2014). Finding an acceptable compromise on such issues has proven to be notoriously difficult as was evidenced in the failed multi-party talks of December 2013, overseen by US diplomats Dr. Richard Haass and Professor Meghan O'Sullivan, that had sought to develop a blueprint for dealing with the "legacy of the past". The failure to reach an agreement in the talks led Dr. Haass to express the view that although 'much of the world looks to Northern Ireland as a model of peacebuilding' this was very much 'premature' as a result of the major social and sectarian divisions that remain (Haass, 2014).

This paper will argue that one requirement for dealing with these social and sectarian divisions is a better understanding of the Othering processes that have helped to shape political and cultural attitudes in relation to both the out-group and in-group within an ethnic context. One characteristic of the failed efforts at dealing with the legacy of the past has been the ability of both communities to view the conflict as having stemmed only from the Other and an inability to see their own community's role and responsibilities within that. By further situating the Northern Ireland peace process within Paulo Freire's 'critical consciousness' theory, and through an analysis of Othering in relation to the Orange Order, this paper will

\footnotetext{
1 The term 'nationalist' is a general term that incorporates political parties such as Sinn Féin and the Social Democratic and Labour Party (SDLP). Sinn Féin are a republican party and are often described as representing 'the republican community'. Republican and nationalist tend to be used quite interchangeably. Similarly, the term 'unionist' is a general term encompassing the unionist tradition and parties such as the Democratic Unionist Party (DUP) and Ulster Unionist Party (UUP). It also incorporates working class Protestants and unionist paramilitary groups, both of which often self-identify as 'loyalists'.
} 
argue that solutions are to be found in a process of reflection that requires both communities to critically analyse what it is that they claim to represent - politically and culturally - and how their actions are seen to represent these claims from the point of view of the Other. Such a reflection, it is contended, can lead to a challenge of current political strategies that continue to emphasise an exclusive notion of the nation rather than one based on the inclusivity they often claim to represent.

To develop this, the paper will argue that there is a particular role for university programmes of community-based education in helping to break down what Marsella (2005) describes as long-held 'cultural constructions of reality' - those beliefs and views that are central in defining how groups view themselves and others. It will be argued that a programme of adult education - both formal and informal - can play an important role in highlighting the complexities of "our" realities and can, in a non-threatening and progressive manner, encourage processes of critical engagement capable of facilitating positive transformative processes (Riggins, 1997).

\section{'Othering' and the development of conflict}

To understand the sectarian divisions that continue to blight Northern Ireland society it is necessary to understand both the causes of conflict in the first instance, but also the cultural factors that help to sustain divisions long after the fighting has ended (Richmond, 2005). An important dimension of this is understanding how conflicting groups have come to perceive themselves and each other and how such perceptions have the ability to impact the transition out of conflict (Riggins, 1997; Rothman, 1997). Marsella (2005), in his analysis of culture as 'a critical determinant of conflict' (p. 653), states that diversity and difference, 'when codified and embedded in "unassailable" belief systems', has the ability to provoke and sustain conflict. He further argues that this violence will be 'grounded within a series of factors that are embedded within culturally constructed perceptions' which, for the purposes of this paper, include:

- Perception of danger to national or group survival, identity, well-being.

- Perception of “Other" as evil, dangerous, threatening.

- Perception of self as self-righteous, moral, justified, and "good" by virtue of religion, history, identity (Marsella, 2005: 653). 
Central to the shaping of these 'culturally constructed perceptions', therefore, is the process of Othering which is a crucial component in defining attitudes of in-group 'selfrighteousness' over the lesser and threatening Other (Riggins, 1997).

Weis (1995) defines Othering as a process that 'serves to mark and name those thought to be different from oneself' (pp. 18-19). Grove and Zwi (2006) develop this by arguing that Othering also 'defines and secures one's own identity by distancing and stigmatising an(other)' and claim that its 'purpose is to reinforce notions of our own "normality", and to set up the difference of others as a point of deviance' (p. 1933). The process of Othering, therefore, is a component part of identity formation which, by necessity, 'involves two criteria of comparison between persons or things: similarity and difference' (Jenkins, 2004, p. 4). This has been a central plank in the process of nation-building since the eighteenth century (Gellner, 2006; Kumar, 2000). Colley (1992), part quoting Peter Sahlins (1989), argues that:

...national identity is defined 'by the social or territorial boundaries drawn to distinguish the collective self and its implicit negation, the other,' rather than being dependent on objective criteria such as language, or race or cultural uniformity. Quite simply, we usually decide who we are by reference to who and what we are not (p. 311).

A significant consequence of this is that there is a tendency to look at the Other as in some way lesser (Bourdieu, 2010 [1984]). There is a genuinely held belief that "our culture" is superior to that of the Other and this is grounded in a particularly positive interpretation of “our” nation's historical development and enlightenment (Marsella, 2005; Greenfeld, 1993). Subsequently, there is an unwillingness to accept any critique of an interpretation of history that essentially defines "us"; an unwillingness, Marsella (2005) argues, that is due in large part to the fact that such critiques will 'introduce unacceptable levels of uncertainty and doubt' about our 'cultural constructions of reality' (p. 653).

These 'cultural constructions of reality' are initially shaped by the processes of Othering that are firmly located in the roots of a conflict. If that conflict becomes embedded and long term the 'cultural constructions of reality' then come to play a crucial role in sustaining Othering across generations. In areas blighted by a conflict that is both historic and seemingly intractable, it is necessary to explore in more detail how Othering successfully transmits historical divisions into the contemporary and, in so doing, gives them a continued resonance. 
It is important, therefore, to recognise Othering as a 'sociological process' that acts 'as a resource in social stratification and social closure' (Brewer \& Higgins, 1998, pp. 9-10):

To locate a sociological process is to render its origins and use in terms of the "social item" it produces, describing its character and form as they help to produce this social item. The social item can be anything from the transmission of culture between the generations, the allocation of people into economic strata or the creation of a division of labour between family members (p. 11).

In seeking to analyse Othering as a sociological process a number of key aspects need to be considered. Firstly, Othering should not be viewed simply as a one-dimensional process wherein competing groups come to view the Other negatively over a long period of time. In order for Othering to be successfully transmitted between generations the negative perceptions of the Other need a contemporary resonance - perceived historic stereotypes need a relevance in the here and now. As such, the actions of the Other become a crucial element in the construction of "our reality" and will be seen to lend weight to negative perceptions (Marsella, 2005). It is important, therefore, to understand not only each in-groups perception of the Other but also to understand how the actions of the Other are seen to give credence to these perceptions.

This leads to a second, but very much related consideration, which centres on the contradictions that often lie at the heart of Othering. As discussed above, each group will come to define itself as morally superior to the Other and this is normally 'by virtue of religion, history, identity' (Marsella, 2005, p. 653). This superiority often lends itself to a desire to undermine or suppress the Other which is further reinforced by the perceived threat that the Other represents to the in-group's identity, perhaps even existence. With the rise to prominence of liberal democracy, however, aspirations towards suppression of the Other becomes increasingly complex. Often, the political identity of the in-group will centre on a belief that "we" best represent liberal and democratic values whilst the Other will be viewed as rooted in illiberalism and despotism. However, due to the perceived threat posed by the Other, the in-group's liberalism will very often be compromised in the name of security (Brewer \& Higgins, 1998, pp. 5-7). Policies of exclusion, discrimination and persecution will often be employed to protect against the perceived threat but such policies, as discussed above, merely serve to give credence to the negative perceptions already held by the Other towards the in-group wherein the latter is deemed the illiberal and despotic. 
A final but vital consideration in relation to Othering as a sociological process is its populist character. Othering is capable of mobilising, at any given moment, large sections of the population around particular beliefs about both the in-group and the Other. Of great importance is the negative impact that this populism has on the positive ideals that each ingroup claims to represent. This is of particular importance in areas of national dispute as it will generate a more chauvinistic brand of national expression that is in stark contrast to the liberal, civic nationalism most groups claim to represent. This populism, therefore, becomes a crucial issue as efforts to find political settlements - often at an elite level - begin to take shape.

These issues have been very much evident in Irish history and, more recently, Northern Ireland, where, almost twenty years after the signing of a peace agreement, society continues to be characterised by sectarian divisions that occasionally give rise to outbreaks of inter-communal tensions and violence (Nolan, et al., 2014). This has certainly been the case in relation to Orange Order parades, which continue to create the conditions for conflict in certain areas: even at a time when the influence of the Order is seemingly on the decline (McAuley, et al., 2011; Kaufmann, 2007). Tracing the history of Othering in association with the Orange Order provides a useful example of the processes described above and may also shed greater clarity on how such issues can be confronted.

\section{Orangeism and "Othering": A History of Division}

The Orange Order is a 'Protestant fraternity' established in 1795 for the dual role of promoting Protestant interests in Ireland and celebrating the memory of King William of Orange, particularly his symbolic victory over the Catholic King James at the Battle of the Boyne in 1690 (Kennaway, 2006; See also Grand Orange Lodge of Ireland, i).

The 'Qualifications of an Orangeman', effectively the Constitution of the Order, state that its members:

... should love, uphold, and defend the Protestant religion, and sincerely desire and endeavour to propagate its doctrines and precepts; he should strenuously oppose the fatal errors and doctrines of the Church of Rome, and scrupulously avoid countenancing (by his presence or otherwise) any act or ceremony of Popish Worship (quoted in Kennaway, 2006: 268). 
Despite this strong emphasis on religion, it would be wrong to view the Order as simply a religious organization (McAuley, et al., 2011; Bryan, 2000). Kaufmann (2007) argues that the Order is 'an extremely multifaceted organization which must be considered in all its manifestations: cultural, religious, convivial, and political' (p. 1). Its stated commitment to protecting Protestant interests, in particular, has given the Order a prominent and often controversial role in some of Northern Ireland's most significant social and political disputes and which has left it open to accusations of anti-Catholicism and sectarianism (Brewer \& Higgins, 1998).

To better understand the Orange Order it is important to contextualise it within the processes of Othering described above. In the first instance, it is possible to identify a clear sense of superiority over the Other 'by virtue of religion, history, identity' (Marsella, 2005, p. 653). From a religious perspective, the Order views Catholicism as idolatrous and its rituals grounded in superstition (Hempton, 1996). Similarly, the ethos of Orangeism is defined by an analysis of British history that pits an enlightened, democratic and Protestant Britain against the dark forces of an Irish nationalism grounded in the illiberalism and despotism of a Catholicism incapable of tolerating difference and enlightenment (Brewer \& Higgins, 1998). As one Orange commentator declared in 1899:

It is an undoubted fact that ever since the Reformation Protestants have been the subjects of persecution, and more particularly in our own land have been held up to every species of contempt, their bitter foe being Popery or Romanism, which a celebrated statesman declared to be "not a religion, but a great political scheme aiming at ascendancy.' Popery is unchangeable, and will suffer no rival power to exist...(Niven, 1899: 3).

This highlights a further component of Othering, which centres on the perceived threat posed by the Other (Marsella, 2005). The Orange Order views the Catholic community as a threat to Protestantism in Ireland/Northern Ireland. Importantly, this threat has not just centred on the religious dimension but is seen also within the cultural, economic and political spheres (Kaufmann, 2007). As the Niven (1899) quote highlights, the Order presents an analysis of Irish history that emphasises this threat and which forms the basis of the imagery used in Orange parades to commemorate particular events that are seen to epitomise Protestant persecution such as the massacres of both the 1641 and 1798 rebellions (Brewer \& Higgins, 1998; see also Bew, 2009). 
Such commemorations bring to the fore a third element of the Othering process: how the actions of the Other contribute to sustaining and giving credibility to such negative perceptions. Although symbolic events, such as those 1641 and 1798, are commemorated and play an important role in generating a sense of Otherness, this is sustained and given contemporary relevance by other developments that reinforce the narratives of threat and persecution and which help to popularise the threat posed (Elliot, 2000). The nature of the Catholic Church in Ireland throughout much of the nineteenth and twentieth centuries, for example, did little to dispel Protestant fears that it was indeed 'a great political scheme aiming at ascendancy' (Niven, 1899, p. 3). From the mid-nineteenth century the Church espoused an ultramontane Catholicism that sought to ensure an Irish society completely in line with papal teaching on political, social and moral issues (Elliot, 2000; Hempton, 1996; Connolly, 1985). It argued for a right to control key aspects of Irish society that could impact Catholic moral teaching, with schools and schooling being a primary concern (McGrath, 2000). That there was also seen to be significant clerical involvement within Irish nationalist movements also helped to give further credence to Orange fears about a Vatican led plot for ascendancy (Collins, 2002).

Similarly, the militant nationalism of both the early twentieth century and that which came to characterise Northern Ireland society from the late-1960s, were deemed as yet further proof of an inherent Catholic hostility to Protestantism and British identity (Bew, 2009).

A further characteristic of the Othering process centres on how their sense of superiority, alongside the long-held fears and insecurities of the Other, have generated a form of contradictory politics to emerge within Orangeism and Unionism more generally. Brewer and Higgins (1998), in their discussion of anti-Catholicism in Britain, point out that:

In the seventeenth century...anti-Catholicism was particularly associated with attacks on absolutism in government and the monarchy, and a defence of political liberty and parliamentary democracy. Absolutism was Catholic; Protestantism was associated with liberty, won in hardship by the English Civil War and the Glorious Revolution of $1688 \ldots$ (p. 5).

They further point out, however, that the anti-Catholicism in Britain led to Catholics being denied the vote, being excluded from Parliament and other state offices, and subject to 'punitive taxation and to social restrictions on access to weaponry, education, property and worship' (p. 5). In other words, those claiming to represent 'liberty' became the very people denying that 
liberty to sections of society. Such contradictions are very much evident in relation to the Orange Order.

Orangeism, like Unionism, claims to be 'committed to the cause of Civil and Religious Liberty for all' (Grand Orange Lodge of Ireland, ii). It takes pride in its historical associations with King William of Orange, who it credits with laying the foundations for 'the evolution of Constitutional Democracy in the British Isles' (Grand Orange Lodge of Ireland, i). Politically, the Order has been a key part of the wider Unionist movement that argues for maintaining a British connection, partly on the basis that this 'offers the best means of ensuring civil and religious liberty for all the people of Northern Ireland' (Grand Orange Lodge of Ireland, ii).

Such claims are met with a large degree of scepticism by many within the Catholic community in Northern Ireland (Bew, 2009; Bryan, 2000). Rather, they tend to view the Orange Order as a quasi-political organisation that, far from supporting constitutional democracy, had a central role in shaping discriminatory practices against the Catholic population under the Unionist administration that dominated Northern Irish politics for over fifty years (Bew, et al., 2002).

They point, in support of these claims, to the 'political speeches' that have characterised Orange meetings during the July $12^{\text {th }}$ celebrations. One of the most (in)famous of these, which is well remembered within nationalist folklore, is that of Sir Basil Brooke MP, a future Prime Minister of Northern Ireland, who in July 1933, declared during an Orange meeting that:

...there were a great number of Protestants and Orangemen who employed Roman Catholics. He felt that he could speak freely on this subject as he had not a Roman Catholic about his own place. (Cheers). He appreciated the great difficulty experienced by some of them in procuring suitable Protestant labour, but he would point out that the Roman Catholics were endeavouring to get in everywhere and were out with all their force and might to destroy the power and the constitution of Ulster. This was a definite plot to overpower the vote of Unionists in the North. He would appeal to loyalists therefore, wherever possible, to employ good Protestant lads and lassies (Fermanagh Herald, 1933). ${ }^{2}$

\footnotetext{
${ }^{2}$ The Fermanagh Herald was/is predominantly read by members of the Catholic/Nationalist community.
} 
Perhaps even more symbolical was the then Northern Ireland Prime Minister, Sir James Craig's declaration, again well engrained in nationalist memory, that he was 'an Orangeman first and a politician and Member of this Parliament afterwards' and his 'boast' that 'we are a Protestant Parliament and Protestant State' ${ }^{3}$

For many within the Catholic community the Orange Order is viewed as representing the uncompromising, anti-Catholic, right wing of Unionism and their parades symbolise a Protestant/Unionist supremacy that dominated Northern Ireland until the early 1970s (Patterson \& Kaufmann, 2007; Bryan, 2000). As a consequence of this there has been a considerable hostility towards Orange parading from within the Catholic population which has, in certain cases, manifested itself in outbreaks of serious violence in areas such as Portadown (Bryan, 2000) and, more recently, the Ardoyne area of Belfast.

\section{Nationalism, Republicanism and the Orange Other}

These disputes over Orange parading can help to shed further light on the process of Othering in Northern Ireland and in particular, on the nature of Othering as a two-way process. Whilst the previous section drew attention to Othering processes within the Orange Order, it is important to recognise similar dynamics within the nationalist community. Such processes have been defined by both a sense of superiority over, and a hostility towards the Orange Order; both of which stem from their sense of persecution under the Unionist government that was influenced by Orangeism (Bew, et al., 2002). This persecution - which took the form of discriminatory practices in areas such as housing allocation, employment opportunities, voting rights and the gerrymandering of political boundaries to maximise unionist returns - helped to foster the idea that Orangeism was grounded in sectarianism and illiberalism (Bew, 2009; Bryan, 2000). In this analysis it was the Catholic population, with its commitment to a citizenship-based republicanism, that were presented as the liberals and democrats.

This narrative became ever more prominent as republicanism, led by Sinn Féin, made the transition away from 'armed struggle' to a peace strategy (English, 2004). Since the late 1970s, Sinn Féin's Gerry Adams had been putting forward an analysis that there needed to be a political solution to what was, he argued, a political conflict. An early example of this can be seen from a speech he delivered at the annual Wolfe Tone commemoration ceremony at Bodenstown in June 1979:

\footnotetext{
${ }^{3}$ Quoted in Parliamentary Debates, Northern Ireland House of Commons, Vol. XVI, Cols. 1091-95.
} 
[T] he Republic declared in 1916...cannot be fully re-established solely by military means...the re-establishment of the Republic needs more than a military alternative to the establishment... [O]ur most glaring weakness to date lies in our failure to develop revolutionary politics and to build a strong political alternative to so-called constitutional politics (Quoted in Adams, 1997: 278).

The 'political alternative' referred to here, took the shape of an approach described as 'active republicanism' which Adams had started to espouse in his 'Brownie' articles in An Phoblacht 4 (Adams, 1997). In its early years, it aimed to raise the grassroots political profile of Sinn Féin, which, at that time, continued to play only a secondary and supportive role to the IRA (English, 2006; Feeney, 2002). As part of the strategy, republicans, including Sinn Féin activists and IRA ex-prisoners, were encouraged to participate in or establish community organisations that would work on essentially local issues (Feeney, 2002). In certain areas, of course, it thrust republicans into the already thorny issue of Orange parading in predominantly nationalist areas. During the 1990s, for example, IRA ex-prisoners such as Brendan MacCionnaith in Portadown and Gerard Rice in the Lower Ormeau, rose to prominence as spokespersons in their communities against local Orange parades which they claimed were symbolic of Protestant supremacy:

It is not the 'right to march' that is being asserted, or a simple 'celebration of culture', as the Order maintains. Marching through Catholic areas against the wishes of the local residents is about flaunting the symbols of Protestant supremacy and the culture of unionist domination. It matters desperately to the Orange Order to hold on to some sense of a past in which unionists controlled the economy, government, the civil service, the police and the media... (Garvaghy Residents, 1999: xiii)

Significantly, such opposition to contentious Orange parades aided Sinn Féin efforts to develop the peace process at critical junctures during the 1990s. At this time it became an imperative that the difficult transition into electoral politics did not divide the wider republican movement, some of whom believed that any shift away from militancy was a surrender of republican ideals and an acceptance of British rule in Northern Ireland (English, 2006). By standing up to what was perceived as the great bastion of 'Protestant supremacy',

\footnotetext{
${ }^{4}$ An Phoblacht or Republican News (APRN) is a republican newspaper that, in the main, gives voice to Sinn Féin's line.
} 
primarily through political activity, Sinn Féin were able to send out a clear message to republican doubters that politics could bring about real and meaningful change (Adams, 1997).

This was also a dangerous strategy for the Republican leadership, however. Sinn Féin, as a republican party committed to the 1916 Proclamation of Independence which demands that all children of the nation be cherished equally (English, 2006), could not be seen as opponents of Irish Protestant/Orange culture per se. Indeed, particularly in more recent times, the party leadership has sought to emphasise that it was only particular elements of Orangeism that it was opposed to and only a small number of contentious Orange marches. Despite such claims, the narrative within grassroots republicanism during the 1980s and 1990s was often one of outright hostility towards the Orange as tensions increased over particular disputes that often resulted in outbreaks of serious sectarian rioting (Bew, 2009; Bryan, 2000). This hostility continues to be reflected today in occasional attacks on Orange Halls in areas not associated with any parading disputes.

What is more, the divisions caused by these parading disputes, have left a wider legacy. Not only has it promoted notions of 'supremacy' over the sectarian Other within the Catholic community, but also it has served to cement unionist fears and suspicions in relation to their Other. For members of the Orange Order, the events surrounding Drumcree in the 1990s and Ardoyne more recently, have merely given further credence to their 'truths' that the nationalist population cannot accept anything Protestant and that they will do anything they can to undermine Orangeism. There is a particular belief that republicans have strategically targeted the institution and that this makes a mockery of their claims to support an independent Ireland grounded on equality for all its citizens. In a speech made in January 2014, at the reopening of Seagoe Orange Hall in Portadown which had been badly damaged in an arson attack, the Grand Secretary of the Orange Order, Drew Nelson, stated that since 1969, there had been 'over 350 arson attacks on Orange halls by the republican movement'. Arguing that 'very few' of these attacks happened during conflict itself, he further contended that:

In the late 1980s, for some reason, the republican movement turned their attention to the Orange Order. They started to organise their opposition to our parades and to burn our Orange halls (Nelson, 2014). 
A final important characteristic of Othering that needs consideration centres on the populist nature of the process. Othering, in both its formation and sustenance, has not been confined to one particular aspect of social life in Northern Ireland but, rather, branches out across society. Thus, the religious and political divisions of the nineteenth and twentieth centuries, came to be reflected in every day, popular activities such as sports played/teams supported and the cultural organisations associated with. One important consequence of this is that it has helped, however ill-defined it may be, to politicise a wider section of the populace into an 'us' and 'them' political culture. As discussed above, this political culture does not necessarily relate to the historic ideals supposedly at the heart of either Irish nationalism or Ulster Unionism, but is rooted primarily in a politics defined by Othering.

The implications of this have been seen most recently as a result of the banned Orange march in the Ardoyne area of North Belfast. As McAuley, Tonge and Mycock (2011), Kaufmann (2007) and Nolan (2014) highlight, membership of the Orange Order has declined significantly over the past number of decades. During the late 1940s the Order could boast a membership of almost 80,000; more recently, that number is closer to 35,000 (BBC News, 2009). Yet, this falling membership does not signify a total collapse in support for the Orange Order. Indeed, as the dispute in Ardoyne has shown, the Order continues to gain support from elements across the wider Protestant, unionist and loyalist communities who, irrespective of the differences they have with Orangeism, continue to lend it support as being of 'us' and against 'them' (McDonald, 2015).

This populist character of Othering needs to be considered within the framework of the Northern Ireland peace process, which has been a largely elite driven process. As such, it has failed to fully address the very real divisions that continue to characterise that society at a grassroots levels and which are not necessarily ideologically based (Nolan, 2014; see also Rowan, 2015).

\section{Othering and Conflict Transformation in Northern Ireland}

The political situation in Northern Ireland has, unquestionably, been transformed by the peace agreement of 1998 and the subsequent agreements at St. Andrews in 2007 and Hillsborough in 2010 (Rowan, 2015). Yet, it is becoming increasingly clear that the ending of a military conflict does not bring with it a change in how conflicting groups view each other (MacGinty, et al., 2007; Richmond, 2010; Richmond, 2005). Long-held negative perceptions of the Other do not end with the signing of a peace agreement and, as such, the causes of 
conflict, albeit a lower level form of conflict, continue to exist (MacGinty, et al., 2007; Steenkamp, 2005). This has been particularly true in those 'interface' areas of Belfast where tensions over issues such as Orange parades and the flying of flags continue to lead to outbreaks of intercommunal violence, which, in turn, help to perpetuate communal divisions (Cummings, et al., 2016). That such divisions remain in place, almost twenty years after the Agreement, raises important questions about the processes of conflict transformation that have been employed in Northern Ireland.

Throughout the years of conflict two contrasting models for advancing peace were advocated: an "integrationist"/“civil society" approach and a consociational method (Kerr, 2006, pp. 11-13; Dixon, 1997).

The "integrationist" or "civil society" model emphasises the need for a "bottom-up" approach and argues for the "extension of democracy and greater interethnic contact as a means of resolving conflict' (Dixon, 1997, p. 3). It is grounded in the belief that:

Increasing interethnic contact breaks down sectarian barriers and promotes a political environment more conducive to accommodation. This 'bottom-up' approach argues that civil society tends to be more 'compromising' or 'moderate' than its political representatives. By extending democracy this 'moderate majority' can put pressure on the politicians to move towards a settlement (Dixon, 1997: p. 3).

Lying at the heart of such an approach are two key assumptions. In the first instance there is a view that the ethnic aspect of the conflict is not as deep as is often assumed and can, over time, be transformed (Taylor, 2001). It is argued that there is a need to develop a strong centre ground capable of challenging current ethno-national identities and marginalising the extremes. The second assumption is that the conflict is rooted, not in an ethno-national divide but rather is the consequence of 'an unjust social order'. In the Northern Ireland example, this is evidenced in 'the lack of civil rights, widespread discrimination, and socio-economic inequalities' that characterised Northern Ireland under the Unionist administration (Taylor, 2001, pp. 45-46). As such, socio-economic equality between Catholic and Protestant would remove a key cause of conflict (Bew \& Patterson, 1990).

The alternative model advocated is that of consociational democracy. In contrast to the bottom-up approach espoused by "integrationists", the consociational theory advocates a 
top-down model wherein the priority is a solution at a political elite level. Lijphart (1977), a prominent figure in developing the theory, argues that the 'mass public' tends to be 'rather passive and apolitical almost everywhere and therefore does not present a great danger to the possibilities of elite accommodation' (p. 53). Political institutions, therefore, are seen as a primary mechanism for generating greater stability by their ensuring that 'all significant segments of the plural society cooperate in a grand coalition to govern the country' (p. 25).

In presenting a critical analysis of Lijphart's early consociational theory, however, McGarry and O'Leary $(2009 ; 2006)$ argue that it was inadequate for dealing with deeply divided societies and, particularly, those societies deemed 'pluri-national' (2009, p. 25). This was especially relevant in Northern Ireland which, they insist, is 'best understood as a binational place' (p. 25). Unlike the "integrationist" analysis, they stress the ethno-nationalist roots of the conflict and argue that the failure of a middle-ground to emerge throughout the years of conflict proves the durability of these divisions (McGarry \& O'Leary, 2009; see also Kerr, 2006; McGarry, 1998). Consequently, they stress the need to recognise the legitimacy of the differing national aspirations and that this must be central to any consociational model applied. They argue that:

...consociational institutions may be too integrationist for national minorities. This observation is obvious when nationalist movements seek secession because consociation is normally associated with institutional arrangements that maintain the territorial integrity of the existing state. "Integrationists" often forget that consociation may be considered territorially "integrationist" by nationalists unhappy with the existing state (2009: p. 26).

To overcome this weakness McGarry and O'Leary argued the need for institutions to extend beyond the internal consociation advocated by Lijphart (McGarry \& O'Leary, 2009). In Northern Ireland this meant, minimally, 'all-island and all-Ireland cross-border institutions, and institutions linking the two sovereign governments of the United Kingdom and Ireland in confederal ways' (p. 24).

Both of these models have become central in advancing the peace process in Northern Ireland. The consociational model developed by McGarry and O'Leary became the cornerstone of the political institutions enshrined within the Agreement (Taylor, 2009) whilst the integrationist model continues to influence community relations policies and projects 
supported by European and governmental peace funding. Yet, as alluded to earlier, sectarian divisions continue to blight Northern Ireland society.

A primary reason for this is that both of the models described above have failed to adequately consider the nature and extent of Othering at a grassroots level, and its ability to negatively impact group relations in spite of the political progress made over the past twenty years (Richmond, 2010). The integrationist approach lays too much emphasis on the ability of social and economic reform to cure societal divisions that are grounded in Othering whilst the consociational arrangements established under the Agreement largely ignore the significance of grassroots division. This is crucial when considered within the context of Othering and its ability to politicise larger sections of the population than would normally be the case undermining Lijphart's claim that the masses tend to be 'passive' or 'apolitical' (Lijphart, 1977, p. 53). Indeed, not only is this issue not fully appreciated, the focus on solutions driven by the elite may also help to perpetuate Othering within the peace process (Taylor, 2006).

Although The Agreement affirms that the constitutional status of Northern Ireland would not change 'save with the consent of a majority of its people' (The Agreement, 1998, p. 3) it also recognises the 'continuing, and equally legitimate, political aspirations' (pp. 2-3) of both communities. As such, Irish nationalists are free to continue working towards their aspiration of Irish unity through peaceful and democratic means. Whilst the former element of The Agreement (consent) provided some reassurance to unionists, the latter aspect restored historic 'fears' and raised the level of suspicion concerning the actions of nationalists when it came to such issues as cultural identity.

Working under the terms of The Agreement, northern Catholics have sought greater recognition and equality for their political and cultural identity (Crowley, 2008; Nic Craith, 2003). ${ }^{5}$ Unionists, however, interpret this as part of a new nationalist strategy designed to undermine the 'Britishness' of the state and advance their cause of Irish unity - an analysis seemingly reinforced by the opposition of Nationalists to Unionist/Protestant culture such as Orange parading, as described above. Such an interpretation has been evident since the early years of the peace process and its manifestation seen in a speech by the then Ulster Unionist Party (UUP) leader, David Trimble, to his party conference in October 2000. Outlining the

\footnotetext{
${ }^{5}$ Under The Agreement, for example, the British government are required, 'where people so desire it' to 'take resolute action to promote' the Irish language (The Agreement, 1998, p. 24)
} 
work being done by the party in the new Northern Ireland government, Trimble was keen to highlight the importance of his party holding the 'Culture' portfolio within the Executive:

Michael McGimpsey [then Minister for Culture, Arts and Leisure] knows that culture is going to be a political battleground. He will ensure fair play for our Scots and English heritage (Trimble, 2000).

The idea expressed here, that 'culture' was to be 'a political battleground' demonstrates, in stark terms, how the old themes that helped to define the conflict were merely recreated within the context of the peace process (Bew, 2009). The political elites of both Irish nationalism and Ulster Unionism approached the peace process in a largely defensive manner, with their priority being to protect that which they claimed to espouse during the years of conflict (MacGinty, et al., 2007). For a truly transformative process, there is a need to move beyond such politicking. This requires there to be a focus on the legacy of Othering and, in particular, the nature of politicisation it has generated at a grassroots level. As discussed earlier, whilst Othering has politicised larger sections of the community, the politics that has emerged tends to be contradictory in nature and often stands in stark contrast with what the different communities claim to represent. As such, what is required, in order to advance a fuller transition to a peaceful society, is a programme of grassroots based political education capable of facilitating critical consciousness.

\section{Transformative Education and the Legacy of the Past}

In 1974, the Brazilian educationalist Paulo Freire published his essay Education for Critical Consciousness. Freire's concerns in the essay centred on Brazil's efforts to transition from one epoch - characterised as a "closed society" that was culturally alienated - into another that would be democratic and 'homogeneously open' (Freire, 2013 [1974], pp. 7-8). Such a transition, Freire argued, was essential for the country's economic and political future (Kirkendall, 2010). Despite this necessity the transition was problematic as it required a new type of society to emerge; a society that was seen to potentially threaten the old order who wanted to protect their status:

Some groups truly believed that the increasing political participation of the people during the transitional epoch would make it possible to achieve an open, autonomous society without violence. Other, reactionary, forces sought at all costs to obstruct any advance and to maintain the status quo indefinitely...Men 
and institutions began to divide into two general categories - reactionaries and progressives...(pp 8-9).

Freire maintained that the uncertainty generated by transition played into the hands of those opposed to change who felt threatened by the rising tide of democracy. By resorting to a form of sectarian politics, they were capable of preventing change and erecting a barrier to full transition. Importantly, Freire describes the nature of sectarianism:

Sectarianism is predominantly emotional and uncritical. It is arrogant, antidialogical and thus anticommunicative. It is a reactionary stance...

Disrespecting the choices of others, [the sectarian] tries to impose his own choice on everyone else. Herein lies the inclination of the sectarian to activism: action without the vigilance of reflection; herein his taste for sloganizing, which generally remains at the level of myth and half-truths and attributes absolute value to the purely relative (p. 9).

For Freire the sectarian 'sets himself up as the proprietor of history, as its sole creator, and the one entitled to set the pace of its movement' (p. 9) and, as such, seeks to impose their convictions on the people who are reduced to 'mere masses':

The sectarian wishes the people to be present at the historical process as activists, maneuvered by intoxicating propaganda. They are not supposed to think.

Someone else will think for them; and it is as protégés, as children, that the sectarian sees them (p. 10).

The alternative for Freire centred on a process of 'radicalization' that he seen as the very antithesis of sectarianism:

Radicalization involves increased commitment to the position one has chosen. It is predominantly critical, loving, humble, and communicative, and therefore a positive stance. The man who has made a radical option does not deny another man's right to choose, nor does he try to impose his own choice. He can discuss their respective positions. He is convinced he is right, but respects another man's prerogative to judge himself correct. He tries to convince and convert, not to crush his opponent (p. 9). 
For radicalism to flourish, Freire argued, there is a need for increased levels of critical consciousness that enables the populace to 'integrate themselves into a transitional society, marked by intense change and contradictions' (p. 13):

What was needed was to go to the people and help them to enter the historical process critically. The prerequisite for this task was a form of education enabling the people to reflect on themselves, their responsibilities, and their role in the new cultural climate - indeed to reflect on their very power of reflection' (p. 13).

It is important, however, that any such reconstruction is primarily self-generated by the 'ingroup' and not imposed in a manner that merely reflects the sensitivities of 'an Other' (Hall, 1998). As Freire argues, solutions to the issues raised within a transitionary period need to be 'solutions with the people and never for them or imposed upon them' (p. 13). ${ }^{6}$

Central to any process of transition, therefore, is the need for programmes of education that help to empower each in-group to critically reflect upon their conceptions of 'reality' and to contextualise these within wider political and cultural aspirations pertinent to the new epoch (Golan \& Shalhoub-Kevorkian, 2014).

This is certainly appropriate for Northern Ireland as it seeks to continue its own transition between epochs. Although the divisive ideals of British Union or Irish Unity remain key characteristics within the era of peace, the transition away from conflict requires the political groupings to reconstitute their aims and aspirations to the demands of the new epoch. Central to this is an analysis on how they incorporate the Other into their political vision rather than seeing them simply as a problem (Rothman, 1997). The starting point in such a process is a critical reflection on 'us', and in particular, on 'our' role in helping to create and sustain the conditions for conflict and division. Moreover, there is a need to critically explore the relationship between what we claim to stand for and what our actions suggest we actually stand for.

The university has an important role to play in this process. Freire (1996 [1970]) argues that when it comes to solving epoch defining problems, it needs to be about finding 'solutions with the people and never for them or imposed upon them' (p. 13). The university is ideally suited to deliver an 'education for critical consciousness' that will enable such a process to take place (Freire, 1996 [1970]). Through short programmes of adult and community

\footnotetext{
${ }^{6}$ Emphasis in the original text.
} 
education, the university, using its scholarly expertise and academic accountability, can provide a model of learning that encourages critical thinking and analysis and which enables the populace to participate more fully in the political process and confront the contradictions inherent in Othering (Tett, 2002). Such a programme of education should, in many ways, reflect the radical pedagogy employed by Freire in Brazil:

Instead of a teacher, we had a coordinator; instead of lectures, dialogue; instead of pupils, group participants; instead of alienating syllabi, compact programs that were "broken down" and "codified" into learning units. In the culture circles, we attempted through group debate either to clarify situations or to seek action arising from that clarification. The topics for these debates were offered us by the groups themselves (Freire, 2013 [1974]: 40).

Such a programme of education has already played an important role in helping to bring about the peace process. McManus (2016), exploring the nature of nationalism in Northern Ireland during the 1960s, argues that nationalist sentiment was unevenly spread across the Catholic population due to the nature of the educational system wherein those attending secondary schools did not acquire the same 'national' education as their counterparts in the more academic grammar schools. He claims that as the IRA re-emerged it was largely young people from working-class communities, those least likely to have obtained a grammar school education, that joined the movement (p. 52). This meant that 'the traditional ideology of Irish nationalism and republicanism was not necessarily a driving motivation for new recruits' (p.52) - a situation that changed as the militancy developed:

The primary mechanism for bringing this about was through a significant programme of internal debates, discussions and classes held in the prisons from the 1970s. These debates, organised by the more politically minded figures, aimed to advance the political dimension of the republican struggle... (McManus, 2016, p. 52).

Throughout the 1970s and 1980s this internal debate slowly helped to facilitate a shift away from militancy as republicans critically evaluated their 'long war' and its liklihood for success (English, 2004). Such programmes, were of course, very much limited to those within the republican movement and, more often than not, in prison. 
There now exists the need for a similar, but much extended programme capable of generating greater critical consciousness. The key component of such a programme is that it challenges its participants to critically reflect upon what they perceive to be 'their reality' and challenge the stereotypes they hold about the Other. In the example of Orange parading disputes analysed in this paper, there is a need to critically discuss, with members of the Order, why Catholics might oppose its parades and assess what role the Orange has had, through its actions, in shaping such opposition. Similarly, there is a need to discuss with nationalists and republicans how they have contributed to this process. Although republicans have sought to build their peace process discourse around the idea of 'equality', for members of the Orange Order this sits in stark contrast to the experiences they see before them each summer when republicans are seen to be opposing equality for the Orange (see Green Hat, 2014: 71).

The second element of this educational process is largely related to strategy. This requires participants to build upon earlier discussions with the aim being to explore how individuals/groups can ensure that what they claim to stand for is better reflected in their actions (Rothman, 1997). This is very much related to Freire's notion of seeking action from clarification (Freire, 2013 [1974]). Within this the onus is on each group to consider mechanisms that work towards their stated ideals but which turns the emphasis upon the need for inclusivity. As Rothman (1997) has argued:

Identity conflict is about who we really are and what we care about most deeply. Such conflict may be creatively transformed when adversaries come to learn, ironically perhaps, that they may fulfil their deepest needs and aspirations only with the cooperation of those who most vigorously oppose them. Even while cooperating, adversaries may still wish the other side would just go away; peace prevails when they understand that this will not happen (p. xiii).

The programmes for critical consciousness must not focus solely on local disputes around parading, therefore, but rather contextualise these within the wider political situation. The programme/s should explore and challenge the 'nationalisms' that shape the political culture in Northern Ireland and which continue to give credence to exclusive interpretations of what each 'nation' looks like. Participants should be encouraged to reflect upon the 'imagined' character of the nation (Anderson, 1991) and analyse how such 'imaginings' can better reflect the realities of a diverse society. Unionists, therefore, need to reflect upon their ideas of 
'Britishness' and how this incorporates Irish Catholicism; similarly nationalists and republicans need to explore their perceptions of 'Irishness' and how this might better reconcile with the Ulster Protestant/British identity.

Finally, it is important that such programmes begin on the basis of single-identity discussions. Although cross-community work is an essential part of conflict transformation, the programmes described above need to provide space for participants to reflect upon the transition from one epoch to another and what that means for their 'community'. The singleidentity aspect of the programmes ensures that each community takes ownership of their transition and nullifies any sense that this is a transition being forced upon them by the Other.

\section{Conclusion}

Northern Ireland has changed dramatically over the past twenty-years. An area previously characterised by conflict and instability is no longer making the daily news headlines across the globe with each new killing or atrocity (Bew, 2009). Yet, this transition from one epoch to another has not been easy and is, as yet, incomplete (Rowan, 2015). The sectarian divisions that helped to sustain conflict for over thirty years continue to plague the peace and help to sustain the continuing tensions that surround Orange parades and other cultural conflicts (Nolan, 2014).

This paper has argued that there is a need to confront the legacy of Othering in Northern Ireland, which has played a crucial role in shaping sectarian divisions. Through an analysis of attitudes towards the Orange Order, the paper has demonstrated how, in a two-way process, both communities have contributed to the processes of Othering over a considerable period of time. Through a negative stereotyping of the out-group, both sides generate a fear of the Other but also instil a measure of superiority within their own in-group. Importantly however, they also, in reacting to both their sense of superiority and fears, take actions that help to feed the Othering process within the out-group as well. These actions, which are usually grounded in an exclusive interpretation of the national ideal, will appear to contradict those values that they claim to represent and which form the basis of their sense of superiority.

It has been argued that the best mechanism to confront Othering is through a University programme of 'transformative education' that can increase critical consciousness and allow the wider populace to reflect on their perceived 'realities' and how these might lend themselves to conflict. It has been contended that Othering helps to generate a populist form 
of politics wherein larger sections of the population become politicised than would normally be the case. As such, there is a need for a grassroots-based programme that facilitates an internal critical reflection on how political ideals may be better furthered within the context of a new epoch that centres on peace and reconciliation rather than the sectarian divisions of the past. 


\section{References}

Adams, G., 1997. Before the Dawn. London: Mandarin Paperbacks.

Anderson, B., 1991. Imagined Communities. London: Verso.

BBC News, 2009. Orange Order members 'in decline'. [Online] Available at: $\quad$ http://news.bbc.co.uk/1/hi/northern_ireland/8126543.stm [Accessed 7 April 2016].

Bew, P., 2009. Ireland: The Politics of Enmity, 1789-2006. Oxford: Oxford University Press.

Bew, P., Gibbon, P. \& Patterson, H., 2002. Northern Ireland, 1921-2001: Political Forces and Social Classes. London: Serif.

Bew, P. \& Patterson, H., 1990. Scenarios for Progress in Northern Ireland. In: J. McGarry \& B. O'Leary, eds. The Future of Northern Ireland. Oxford: Oxford University Press, pp. 206218.

Bourdieu, P., 2010 [1984]. Distinctions: A social critique of the judgement of taste. London: Routledge.

Brewer, J. D. \& Higgins, G. I., 1998. Anti-Catholicism in Northern Ireland, 1600-1998: The Mote and Beam. Basingstoke: Macmillan Press Ltd.

Bryan, D., 2000. Orange Parades: the politics of ritual, tradition and control. London: Pluto.

Colley, L., 1992. Britishness and Otherness: An Argument. Journal of British Studies, 31(4), pp. 309-329.

Collins, K., 2002. Catholic Churchmen and the Celtic Revival in Ireland, 1848-1916. Dublin: Four Courts.

Connolly, S., 1985. Religion and Society in Nineteenth Century Ireland. Dundalk: Dundalgan (for the Economic and Social History Society of Ireland).

Crowley, T., 2008. Wars of Words: The Politics of Language in Ireland 1737-2004. Oxford: Oxford University Press.

Cummings, E. M. et al., 2016. Growing Up On an Interface, Belfast: OFMDFM. 
Dixon, P., 1997. Paths to Peace in Northern Ireland (I): Civil Society and Consociational Approaches. Democratization, 4(2), pp. 1-27.

Elliot, M., 2000. The Catholics of Ulster, A History. London: Allen Lane The Penguin Press.

English, R., 2004. Armed Struggle - The History of the IRA. London: Pan Books.

English, R., 2006. Irish Freedom: The History of Nationalism in Ireland. London: Macmillan.

Feeney, B., 2002. Sinn Féin: A Hundred Turbulent Years. Dublin: The O'Brien Press.

Fermanagh Herald, 1933. Bigoted Outbursts at "Twelfth" Meetings. Fermanagh Herald, 22 July, p. 10.

Freire, P., 1996 [1970]. Pedagogy of the Oppressed. London: Penguin.

Freire, P., 2013 [1974]. Education for Critical Consciousness. London: Bloomsbury Academic.

Garvaghy Residents, 1999. Garvaghy: A community under siege. Belfast: Beyond the Pale.

Gellner, E., 2006. Nations and Nationalism. 2nd ed. Oxford: Blackwell.

Golan, D. \& Shalhoub-Kevorkian, N., 2014. Community-engaged courses in a conflict zone: a case study of the Israeli academic corpus. Journal of Peace Education, 11(2), pp. 181-207.

Grand Orange Lodge of Ireland, ii. What does Orangeism stand for today?. [Online] Available at: http://www.grandorangelodge.co.uk/what-does-orangeism-stand-fortoday\#.VWbYzU3bK70

[Accessed 3 July 2015].

Grand Orange Lodge of Ireland, i. Welcome to the Grand Orange Lodge. [Online] Available at: http://www.grandorangelodge.co.uk/what-is-the-orange-order\#.VWXdGk3bK70 [Accessed 3 July 2015].

Green Hat, 2014. County Fermanagh Grand Orange Lodge: Audit, Good Relations Strategy \& Action Plan, Fermanagh: County Fermanagh Grand Orange Lodge .

Greenfeld, L., 1993. Nationalism: Five Roads to Modernity. Cambridge (Massachusetts): Harvard University Press. 
Grove, N. \& Zwi, A., 2006. Our health and theirs: Forced migration, othering, and public health. Social Science and Medicine, Volume 62, pp. 1931-1942.

Haass, R., 2014. US Congress Committee of Foreign Affairs. [Online] Available at: http://docs.house.gov/meetings/FA/FA16/20140311/101880/HHRG-113-FA16Wstate-HaassR-20140311.pdf

[Accessed 12 August 2015].

Hall, S., 1998. Notes on Deconstructing 'the Popular'. In: J. Storey, ed. Cultural Theory and Popular Culture: A Reader. London: Pearson, pp. 442-453.

Hempton, D., 1996. Religion and political culture in Britain and Ireland: From the Glorious Revolution to the decline of empire. Cambridge: Cambridge University Press.

Jackson, A., 2004. Home Rule: An Irish History, 1800-2000. London: Phoenix.

Jenkins, R., 2004. Social Identity. 2nd ed. London: Routledge.

Kaufmann, E., 2007. Orange Order: A Contemporary Northern Irish History. Oxford: Oxford University Press.

Kennaway, B., 2006. The Orange Order: A Tradition Betrayed. London: Methuen.

Kerr, M., 2006. Imposing Power-Sharing: Conflict and Coexistence in Northern Ireland and Lebanon. Dublin: Irish Academic Press.

Kirkendall, A. J., 2010. Paulo Freire and the Cold War Politics of Literacy. Chapel Hill: University of North Carolina Press.

Kumar, K., 2000. Nation and Empire: English and British National Identity in Comparative Perspective. Theory and Society, 29(5), pp. 575-608.

Lijphart, A., 1977. Democracy in Plural Societies: A Comparative Exploration. New Haven: Yale University Press.

MacGinty, R., Muldoon, O. \& Ferguson, N., 2007. No War, No Peace: Northern Ireland after the Agreement. Political Psychology, 28(1), pp. 1-11. 
Marsella, A., 2005. Culture and conflict: Understanding, negotiating, and reconciling conflicting contructions of reality. International Journal of Intercultural Relations, 29(6), pp. 651-673.

McAuley, J. W., Tonge, J. \& Mycock, A., 2011. Loyal to the Core? Orangeism and Britishness in Northern Ireland. Dublin: Irish Academic Press.

McDonald, H., 2015. Loyalists pelt riot police with missiles in Belfast after Battle of the Boyne march.

[Online]

Available at: http://www.theguardian.com/uk-news/2015/jul/13/orange-order-marchingseason-begins-northern-ireland

[Accessed 7 April 2016].

McGarry, J., 1998. Political Settlements in Northern Ireland and South Africa. Political Studies, 46(5), pp. 853-870.

McGarry, J. \& O'Leary, B., 2006. Consociational Theory, Northern Ireland's Conflict, and its Agreement. Part 1: What Consociationalists Can Learn from Northern Ireland. Government and Opposition, 41(1), pp. 43-63.

McGarry, J. \& O'Leary, B., 2009. Power shared after the deaths of thousands. In: R. Taylor, ed. Consociational Theory: McGarry and O'Leary and the Northern Ireland Conflict. London: Routledge, pp. 15-84.

McGrath, M., 2000. The Catholic Church and Catholic Schools in Northern Ireland - The Price of faith. Dublin: Irish Academic Press.

McKittrick, D. et al., 2004. Lost Lives. Edinburgh: Mainstream Publishing.

McManus, C., 2016. Irish language education and the national ideal: the dynamics of nationalism in Northern Ireland. Nations and Nationalism, 22(1), pp. 42-62.

Nelson, D., 2014. Grand Orange Lodge of Ireland. [Online] Available at: http://www.grandorangelodge.co.uk/news.aspx?id=100489\#.VW8Rms9VhBc [Accessed 22 July 2015].

Nic Craith, M., 2003. Culture and Identity Politics in Northern Ireland. Basingstoke: Palgrave Macmillan. 
Niven, R., 1899. Orangeism: As It Was and Is. Belfast: W\&G Baird Ltd.

Nolan, P., 2014. Northern Ireland Peace Monitoring Report: Number Three, Belfast: Community Relations Council.

Nolan, P. et al., 2014. The Flag Dispute: Anatomy of a Protest, Belfast: Queen's University Belfast.

Patterson, H. \& Kaufmann, E., 2007. Unionism and Orangeism in Northern Ireland since 1945:

The decline of the loyal family. Manchester: Manchester University Press.

Richmond, O., 2010. Resistance the Post-Liberal Peace. Millennium: Journal of International Studies, 38(3), pp. 1-28.

Richmond, O. P., 2005. The Transformation of Peace. Basingstoke: Palgrave Macmillan.

Riggins, S. H. ed., 1997. The Language and Politics of Exclusion: Others in Discourse. California: Sage Publications.

Riggins, S. H., 1997. The Rhetoric of Othering. In: S. H. Riggins, ed. The Language and Politics of Exclusion: Others in Discourse. California: Sage Publications, pp. 1-30.

Rothman, J., 1997. Resolving Identity-Based Conflict in Nations, Organizations and Communities. San Francisco: Jossey-Bass Publishers.

Rowan, B., 2015. Unfinished Peace: Thoughts on Northern Ireland's Unanswered Past. Newtownards: Colourpoint Books.

Sahlins, P., 1989. Boundaries: The Making of France and Spain in the Pyrenees. Berkeley: University of California Press.

Steenkamp, C., 2005. The Legacy of War: Conceptualizing a 'Culture of Violence' to Explain Violence after Peace Accords. The Round Table: The Commonwealth Journal of International Affairs, 94(379), pp. 253-267.

Taylor, R., 2001. Northern Ireland: Consociation or Social Transformation?. In: J. McGarry, ed. Northern Ireland and the Divided World. Oxford: Oxford University Press, pp. 37-52.

Taylor, R., 2006. The Belfast Agreement and the Politics of Consociationalism: A Critique. The Political Quarterly, 77(2), pp. 217-226. 
Taylor, R., 2009. Consociational Theory: McGarry and O'Leary and the Northern Ireland conflict. London: Routledge.

Tett, L., 2002. Policy and Practice in Education: Community Education, Lifelong Learning and Social Inclusion. Edinburgh: Dunedin Academic Press.

The Agreement, 1998. Belfast: Northern Ireland Office.

Trimble, D., 2000. Party that has taken huge risks for peace is determined to make government work. Irish Times, 9 October, p. 6.

Weis, L., 1995. Identity Formation and the Processes of "Othering": Unraveling Sexual Threads. Educational Foundations, Volume 9, pp. 17-33. 